\title{
Trials for increasing the infectivity titer of fowl pox vaccines prepared on SPF embroynated chicken egg and tissue culture
}

\author{
Omar A. B., Amira A. EL-Said, Amal A. Fotouh, Bassiouny A. I. and \\ Nermeen M. Elsayed* \\ Veterinary Serum and Vaccines Research Institute (VSVRI) and *Central \\ Laboratory for Evaluation of Veterinary Biologics (CLEVB).
}

\begin{abstract}
:
The present work was designed to study the effect of DEAE-dextran and Magnesium Chloride $(\mathrm{MgCl})$ on fowl pox virus vaccine (FPV) in order to obtain a maximum titer allowing the massive production of the vaccine.

Fowl pox virus; used for vaccine production; was propagated on embroynated chicken eggs (ECE) and chicken embryo fibroblast $(\mathrm{CEF})$, the virus was inoculated in ECE and CEF without DEAEdextran nor $\mathrm{MgCl}$, and with DEAE-Dextran and $\mathrm{MgCl}$ separately. The time of harvestion was early as one day post inoculation in CEF. The virus titer were higher in case of treated inoculums with DEAEdextran and $\mathrm{MgCl}$ reaching (6.2 and $7.5 \quad \log _{10} \mathrm{TCID}_{50} / \mathrm{ml}$ respectively) on $\mathrm{CEF}$ and (6.2 and $6.7 \log _{10} \mathrm{EID}_{50}$ respectively) on ECE. Fowl pox vaccines (FPV) were prepared before and after DEAE-Dextran and $\mathrm{MgCl}$ treatment. The application of quality control assays revealed the safety, sterility and potency of the prepared vaccines. Immune response of the prepared FPV vaccines were evaluated in chickens using virus neutrization test (VNT). It was found that, the use of DEAE-Dextran and $\mathrm{MgCl}$ with the recommended concentrations could result in increasing the virus titer with reduction in the time of harvestation and accordingly increase the vaccine production and decrease its cost.
\end{abstract}

\section{Introduction}

Fowl pox virus (FPV) is a member of genus Avipox which is brick shaped and measured $270 \times 180 \mathrm{~nm}$ (Tripathy and Reed, 2008).

Fowl pox is characterized by the formation of proliferative lesions and scabs on the skin, and diphtheritic lesions in the upper parts of the digestive and respiratory tracts which is fetal form. Modified live FPV vaccines of chicken embryo or avian cell culture origin are recommended for protection of fowl from FPV infection in endemic areas (OIE, 2012).

Plaque formation by certain rhinoviruses in HeLa cells was enhanced by higher concentrations 
of magnesium in the overlay medium (Fiala and Kenny, 1966; Stott and Tyrrell, 1968). Susceptibility of monkey kidney cells to poliovirus and the release of rhinovirus from HeLa cells was also greatly enhanced in the presence of high levels of $\mathrm{MgCl}$ (Fiala \& Kenny, 1967). $\mathrm{MgCl}$ enhances plaque formation by human adenoviruses in HeLa cell monolayer and that effect is due to an increase in the rate of virus release (Russell et al., 1970). Magnesium ions enhance plaque formation (replication of progeny virus) of lentogenic strains of Newcastle disease virus (NDV) (Sahle et al, 2002).

The enhancement of viral infectivity in cell culture systems by DEAE-Dextran is well documented for a number of viruses (Pango and Mccutchan, 1969 and Sasaki et al, 1981). DEAE-dextran increases the DNA transfication in primary cultured adherent human macrophage (Carel et al., 1997). The onset of CPE appeared earlier and virus titers were higher in case of the use of treated inoculums with DEAE-Dextran in Bovine Ephemeral Fever (BEF), camel pox virus (CPV) and avian influenza virus (AI) (Ayatollah et al, 2007, Zeneib Salama. 2006 and Eman et al, 2011). Also DEAE-Dextran improves in-vitro cultivation of swine influenza virus (Margot et al., 2005) and enhanced retro virus infection efficiency about 3 folds (Lee et al., 1996). The efficacy of introduction for exogenous gene into tissue culture was improved using DEAE-dextran (Yuki et al, 2009).

The present study was planned to evaluate the effect of $\mathrm{MgCl}$ and DEAE-Dextran on FPV used for vaccine production, in a trail to obtain a maximum titer of virus yield consequently allowing massive production of the vaccine.

\section{Materials and methods}

\section{Virulent and vaccinal fowl pox viruses}

Vaccinal (Baudate, egg adapted strain - SATRO Italy company batch no 303092, FPV- CEF adapted strain) and Virulent FPV were supplied from Pox Research Department VSVRI and CLEVB for vaccination and challenge the chickens according to (OIE, 2012).

\section{DEAE-Dextran and $\mathrm{MgCl}$ solutions}

Different concentrations of DEAEDextran (obtained from ICN Biomdical ICN) and $\mathrm{MgCl}$ (obtained from Sigma chemical company) $\quad 10 \mathrm{ug} / \mathrm{ml}, \quad 20 \mathrm{ug} / \mathrm{ml}$, $25 \mathrm{ug} / \mathrm{ml}, \quad 30 \mathrm{ug} / \mathrm{ml}, \quad 40 \mathrm{ug} / \mathrm{ml}$, $50 \mathrm{ug} / \mathrm{ml}, \quad 75 \mathrm{ug} / \mathrm{ml}, \quad 100 \mathrm{ug} / \mathrm{ml}$, $150 \mathrm{ug} / \mathrm{ml}$ and $200 \mathrm{ug} / \mathrm{ml}$ were prepared and sterilized by autoclaving according to Anderson et al (1971).

\section{Tissue culture}

Primary CEF was kindly supplied by CLEVB for propagation and titration of FPV with and without DEAE-Dextran and $\mathrm{MgCl}$ according to Charles and Cunnimgham (1973). 
4. Specific pathogenic free embroynated chicken eggs

SPF embroynated chicken eggs (ECE) kindly supplied from Pox Research department VSVRI and used for propagation and titration of FPV with and without DEAEDextran and for detecting of FPV neutralizing antibodies in egg according to Namaa Abdel-Aziz. (1998).

\section{Experimental chickens}

Two hundred and seventy five Specific pathogen free (SPF) chickens 2 weeks old supplied by CLEVB, were divided into 11 groups 25 chicken for each.

1- Group no (1) vaccinated with field dose $\left(10^{3} \log _{10} \mathrm{EID}_{50} / \mathrm{ml}\right)$ of treated FPV with $\mathrm{MgCl}$ prepared on ECE.

2- Group no (2) vaccinated with field dose $\left(10^{3} \log _{10} \mathrm{TCID}_{50} / \mathrm{ml}\right)$ of treated FPV with $\mathrm{MgCl}$ prepared on CEF.

3- Group no (3) vaccinated with field dose $\left(10^{3} \log _{10} \mathrm{EID}_{50} / \mathrm{ml}\right)$ of treated FPV with DEAE-Dextran prepared on ECE.

4- Group no (4) vaccinated with field dose of $\left(10^{3} \log _{10} \mathrm{TCID}_{50} / \mathrm{ml}\right)$ treated FPV with DEAE-Dextran prepared on CEF.

5- Group no (5) vaccinated with 10x field dose $\left(10^{4} \log _{10} \mathrm{EID}_{50} / \mathrm{ml}\right)$ of treated FPV with $\mathrm{MgCl}$ prepared on ECE.

6-Group no (6) vaccinated with $10 x$ field dose $\left(10^{4} \log _{10} \mathrm{TCID}_{50} / \mathrm{ml}\right)$ of treated FPV with $\mathrm{MgCl}$ prepared on CEF.
7- Group no (7) vaccinated with $10 \mathrm{x}$ field dose $\left(10^{4} \log _{10} \mathrm{EID}_{50} / \mathrm{ml}\right)$ of enhanced FPV with DEAEDextran prepared on ECE.

8- Group no (8) vaccinated with $10 x$ field dose $\left(10^{3} \log _{10} \mathrm{TCID}_{50} / \mathrm{ml}\right)$ of enhanced FPV with DEAEDextran prepared on CEF.

9- Group no (9) vaccinated with field dose $\left(10^{3} \log _{10} \mathrm{EID}_{50} / \mathrm{ml}\right)$ of non enhanced FPV prepared on ECE.

10- Group no (10) vaccinated with field dose $\left(10^{3} \log _{10} \mathrm{TCID}_{50} / \mathrm{ml}\right)$ of non enhanced FPV prepared on CEF.

11- Group no (11) control non vaccinated chickens.

NB: Groups ( 1-2-3-4-11) were challenged with virulent FPV with titer $10^{3} \log _{10} \mathrm{EID}_{50} / \mathrm{ml} 2$ weeks post vaccination .

\section{6 -Serum samples}

Blood samples were collected before and after vaccination from wing vein of chickens and left for coagulation and serum collection to measure the protective level of Fowl Pox antibodies by VNT.

\section{7-Vaccination and challenge}

Vaccination and challenge were carried out according to $\boldsymbol{O I E}$ (2012).

8- Cytotoxicity test for DEAEdextran and $\mathrm{MgCl}$ on $\mathrm{CEF}$ and ECE

The toxic effect of various concentrations of DEAE-dextran and $\mathrm{MgCl}$ (200-150-100-75-50-40$30-25-20-10 \mathrm{ug} / \mathrm{ml}$ ) were tested in ECE and CEF according to Ayatollah et al (2007) 
9-Studying the effect of various concentration of DEAE-dextran and $\mathrm{MgCl}$ on the titer of FPV on CEF cell line

Fowl pox virus was propagated and titrated in CEF cell line without and with addition of DEAE-Dextran and $\mathrm{MgCl}$ in different concentrations according to Ayatollah et al (2007). Titrating of virus infectivity were carried out according to the method described by (Reed and Munch, 1938)

10-Quality control of treated and non treated FPV vaccines

Sterility, safety and potency testes were applied on treated and non treated FPV vaccines as mentioned in OIE (2012).

\section{1-Virus neutrization test}

Virus neutralization test (VNT) was applied on serum samples collected from vaccinated chickens with treated FPV vaccines and currently used FPV vaccine according to $\boldsymbol{O I E}$ (2012).

\section{Results}

1- Cytotoxic effect of DEAEdextran and $\mathrm{MgCl}$ on $\mathrm{CEF}$ and ECE

Table (1) shows that DEAEDextran concentrations higher than $75 \mathrm{ug} / \mathrm{ml}$ were toxic for CEF and concentrations above $20 \mathrm{ug} / \mathrm{ml}$ were toxic for $\mathrm{ECE}$, while $\mathrm{MgCl}$ concentrations above $40 \mathrm{ug} / \mathrm{ml}$ were toxic for CEF and concentrations above $25 \mathrm{ug} / \mathrm{ml}$ were toxic for ECE. 2-Effect of different concentrations of DEAE-dextran and $\mathrm{MgCl}$ on the infectivity titer of FPV on CEF cell.

The best concentration of DEAEdextran were $75 \mathrm{ug} / \mathrm{ml}$ and $50 \mathrm{ug} / \mathrm{ml}$, while the lower concentrations yield lower virus titer. Higher concentrations more than $50 \mathrm{ug} / \mathrm{ml}$ revealed no significant changes in viral titer in CEF, while the best concentrations of $\mathrm{MgCl}$ were $30 \mathrm{ug} / \mathrm{ml}$ and $40 \mathrm{ug} / \mathrm{ml}$ as lower concentrations yields lower virus titer. Higher concentrations more than $40 \mathrm{ug} / \mathrm{ml}$ revealed no significant virus titer increase.

3- Effect of DEAE-dextran and $\mathrm{MgCl}$ on different passages of FPV propagated on CEF and ECE.

FPV mixed with DEAE Dextran and inoculated in CEF and ECE for 10 passages at concentration of $50 \mathrm{ug} / \mathrm{ml}$ for CEF and $25 \mathrm{ug} / \mathrm{ml}$ for ECE. The results are presented in table (3) showed that the virus titer increased gradually from $5.7 \log 10$ $\mathrm{TCID}_{50} / \mathrm{ml}$ in first passage till reach $6.7 \log _{10} \mathrm{TCID}_{50} / \mathrm{ml}$ in the $9^{\text {th }}$ passage however in ECE, the virus titer increased gradually from 5.2 $\log _{10} \mathrm{EID}_{50} / \mathrm{ml}$ in first passage till reach $6.2 \log _{10} \mathrm{EID}_{50} / \mathrm{ml}$ in the $8^{\text {th }}$ passage

Regarding the effect of $\mathrm{MgCl}$ on FPV inoculated in ECE and CEF. Data recorded in table (3) revealed that, the virus titer on CEF increased gradually from $6.0 \log _{10}$ TCID $_{50} / \mathrm{ml}$ in first passage to 7.5 $\log _{10} \mathrm{TCID}_{50} / \mathrm{ml}$ at 8 th passage. While in ECE using of $20 \mathrm{ug} / \mathrm{ml}$ of $\mathrm{MgCl}$ increased the virus titer from 
$5.2 \log _{10} \mathrm{EID}_{50} / \mathrm{ml}$ in the first passages till reach $6.7 \log _{10}$ EID $_{50}$ $/ \mathrm{ml}$ in the passage number 8 .

4-Time of harvestaion for FPV propagated on CEF with DEAEDextran and MgCL

To determine the harvesting time of FPV in which the virus titer was maximum after treatment with DEAE-Dextran and Mgcl CPE was used as indicator. Results presented in table (4) indicated that, the harvestion time for treated FPV propagated on CEF decreased gradually with increasing the number of passages when the virus treated with either DEAE-Dextran or Mgl. The best time for harvesting of FPV was 4 days PI when treated with 50ug/ml DEAE-Dextran at the $6^{\text {th }}$ passage, however, the time for collection of FPV when treated with $30 \mathrm{ug} / \mathrm{ml} \mathrm{MgCl}$ was 4 days PI at the passage no 3 .

5-Quality control of the prepared enhanced FPV vaccines

Sterility test: Bacterial culture of treated FPV vaccines with DEAEdextran and $\mathrm{MgCl}$ on both ECE and CEF proved to be free from any bacterial and fungal contamination.

Safety test: Inoculation of treated FPV vaccine in SPF chickens with 10 times of the recommended dose proved that the produced vaccine was safe to be used in chickens. where the vaccinated birds did not show any undesirable symptoms refer to FP.

Challenge test: Vaccination of SPF chickens with treated FPV vaccines by using wing web stabbing method and challenged with virulent FPV revealed that, the protection percent of vaccinated chickens with treated FPV vaccines with $\mathrm{MgCl}$ and DEAE-dextran propagated on ECE and CEF were $96 \%, 92 \%, 96 \%$ and $92 \%$ respectively, as shown in table (5).

5-Potency test of the treated vaccines in chickens (Virus neutrization test -Alpha procedure)

The results were presented in table (6), it was noticed that, chicken vaccinated with field dose (3.7 $\log _{10} \mathrm{TCID}_{50} / \mathrm{ml}$ ) of non treated FPV propagated on ECE and CEF gave similar NI like the field doses of treated FPV on ECE and CEF with DEAE-dextran and $\mathrm{MgCl}$. Moreover the NI of the vaccinated chickens with treated FPV vaccines $\left(10 \mathrm{x}\right.$ field dose $4.7 \quad \log _{10}$ $\mathrm{TCID}_{50} /$ dose) revealed slight high NI. 
Table (1): Effect of various concentrations of DEAE-Dextran and $\mathrm{MgCl}$ on $C E F$ and $E C E$

\begin{tabular}{|c|c|c|c|c|}
\hline \multirow{2}{*}{ Used conc } & \multicolumn{2}{|c|}{ DEAE-Dextran cytotoxity } & \multicolumn{2}{c|}{ MgCl cytotoxity } \\
\cline { 2 - 5 } & CEF & ECE & CEF & ECE \\
\hline $\mathbf{2 0 0 u g} / \mathbf{m l}$ & $\mathbf{1 0 0 \%}$ & $\mathbf{1 0 0 \%}$ & $\mathbf{1 0 0 \%}$ & $\mathbf{1 0 0 \%}$ \\
\hline $\mathbf{1 5 0 u g} / \mathrm{ml}$ & $\mathbf{7 5 \%}$ & $\mathbf{1 0 0 \%}$ & $\mathbf{1 0 0 \%}$ & $\mathbf{1 0 0 \%}$ \\
\hline $\mathbf{1 0 0 u g} / \mathbf{m l}$ & $\mathbf{5 0 \%}$ & $\mathbf{1 0 0 \%}$ & $\mathbf{1 0 0 \%}$ & $\mathbf{1 0 0 \%}$ \\
\hline $\mathbf{7 5 u g} / \mathrm{ml}$ & $\mathbf{0 \%}$ & $\mathbf{1 0 0 \%}$ & $\mathbf{5 0 \%}$ & $\mathbf{1 0 0 \%}$ \\
\hline $\mathbf{5 0 u g} / \mathrm{ml}$ & $\mathbf{0 \%}$ & $\mathbf{1 0 0 \%}$ & $\mathbf{2 5 \%}$ & $\mathbf{7 5 \%}$ \\
\hline $\mathbf{4 0 u g} / \mathrm{ml}$ & $\mathbf{0 \%}$ & $\mathbf{7 5 \%}$ & $\mathbf{0 \%}$ & $\mathbf{5 0 \%}$ \\
\hline $\mathbf{3 0 u g} / \mathrm{ml}$ & $\mathbf{0 \%}$ & $\mathbf{5 0 \%}$ & $\mathbf{0 \%}$ & $\mathbf{2 5 \%}$ \\
\hline $\mathbf{2 5 u g} / \mathrm{ml}$ & $\mathbf{0 \%}$ & $\mathbf{2 5 \%}$ & $\mathbf{0 \%}$ & $\mathbf{0 \%}$ \\
\hline $\mathbf{2 0 u g} / \mathrm{ml}$ & $\mathbf{0 \%}$ & $\mathbf{0 \%}$ & $\mathbf{0 \%}$ & $\mathbf{0 \%}$ \\
\hline $\mathbf{1 0 u g} / \mathrm{ml}$ & $\mathbf{0 \%}$ & $\mathbf{0 \%}$ & $\mathbf{0 \%}$ & $\mathbf{0 \%}$ \\
\hline
\end{tabular}

"Cytoxocity percent was measured according to the percent of the damage and destruction in the CEF cell sheet and embryo death in ECE.

Table (2): Effect of various concentrations of DEAE-dextran and $\mathrm{Mgcl}$ on the infectivity titer of FPV on CEF cell

\begin{tabular}{|c|c|c|c|}
\hline $\begin{array}{l}\text { DEAE- } \\
\text { Dextran } \\
\text { Used conc }\end{array}$ & $\begin{array}{c}\text { Titer of FPV in CEF } \\
\text { with DEAE-dextean } \\
\text { expressed as } \\
\log _{10} \mathrm{TCID} \mathrm{D}_{50} / \mathrm{ml} \\
\end{array}$ & $\begin{array}{l}\text { MgCl } \\
\text { used } \\
\text { conc }\end{array}$ & $\begin{array}{l}\text { Titer of FPV in CEF } \\
\text { with Mgcl expressed } \\
\text { as } \log _{10} \mathrm{TCID}_{50} / \mathrm{ml}\end{array}$ \\
\hline $0 \mathrm{ug}$ & 5.5 & $0 \mathrm{ug}$ & 5.5 \\
\hline $10 \mathrm{ug}$ & 5.5 & $10 \mathrm{ug}$ & 5.5 \\
\hline $25 \mathrm{ug}$ & 5.5 & $20 \mathrm{ug}$ & 5.7 \\
\hline $50 \mathrm{ug}$ & 5.7 & $30 \mathrm{ug}$ & 6.0 \\
\hline $75 \mathrm{ug}$ & 5.7 & $40 \mathrm{ug}$ & 6.0 \\
\hline
\end{tabular}


Table (3): Titration of serial FPV passage in CEF and ECE presence and absence of $\mathrm{MgCl}$ and DEAE-dextran

\begin{tabular}{|c|c|c|c|c|c|c|}
\hline \multirow[b]{2}{*}{$\begin{array}{l}\text { No of } \\
\text { passages }\end{array}$} & \multicolumn{3}{|c|}{ Titer expressed as $\log _{10} T C I D_{50} / \mathrm{ml} \mathrm{in}$} & \multicolumn{3}{|c|}{$\begin{array}{c}\text { Titer expressed as } \log _{10} \text { EID }_{50} / \mathrm{ml} \mathrm{in} \\
\text { ECE }\end{array}$} \\
\hline & $\begin{array}{c}\text { Treated FPV } \\
\text { in CEF with } \\
\text { DEAE- } \\
\text { dextran } \\
50 \mathrm{ug} / \mathrm{ml}\end{array}$ & $\begin{array}{c}\text { Treated } \\
\text { FPV in } \\
\text { CEF with } \\
\text { MgCl } 30 \\
\text { ug/ml }\end{array}$ & $\begin{array}{l}\text { Non- } \\
\text { Treated } \\
\text { FPV in } \\
\text { CEF }\end{array}$ & $\begin{array}{c}\text { Treated FPV } \\
\text { in ECE with } \\
\text { DEAE- } \\
\text { dextran } \\
25 \mathrm{ug} / \mathrm{ml}\end{array}$ & $\begin{array}{c}\text { Treated } \\
\text { FPV in } \\
\text { ECE with } \\
\text { MgCl } \\
20 \mathrm{ug} / \mathrm{ml} \\
\end{array}$ & $\begin{array}{c}\text { Non- } \\
\text { Treated } \\
\text { FPV in } \\
\text { ECE }\end{array}$ \\
\hline 1 & 5.7 & 6.0 & 5.5 & 5.2 & 5.2 & 5.0 \\
\hline 2 & 5.7 & 6.2 & 5.5 & 5.2 & 5.5 & 5.0 \\
\hline 3 & 6.0 & 6.5 & 5.7 & 5.2 & 5.5 & 5.2 \\
\hline 4 & 6.2 & 6.7 & 5.7 & 5.5 & 5.7 & 5.2 \\
\hline 5 & 6.2 & 6.7 & 5.7 & 5.7 & 6.0 & 5.2 \\
\hline 6 & 6.5 & 7.0 & 6.0 & 5.7 & 6.2 & 5.5 \\
\hline 7 & 6.5 & 7.2 & 6.0 & 6.0 & 6.5 & 5.5 \\
\hline 8 & 6.5 & 7.5 & 6.0 & 6.2 & 6.5 & 5.5 \\
\hline 9 & 6.7 & 7.5 & 6.2 & 6.2 & 6.7 & 5.7 \\
\hline 10 & 6.7 & 7.5 & 6.2 & 6.2 & 6.7 & 5.7 \\
\hline
\end{tabular}

Table (4): Time of harvestaion for enhanced and non enhanced FPV in $C E F$.

\begin{tabular}{|c|c|c|c|c|c|c|c|c|c|c|c|c|c|c|c|}
\hline & \multicolumn{5}{|c|}{$\begin{array}{c}\text { Treated FPV with } 50 \mathrm{ug} / \mathrm{ml} \\
\text { DEAE-Dextran }\end{array}$} & \multicolumn{5}{|c|}{$\begin{array}{l}\text { Treated FPV with 30ug/ml } \\
\text { Mgcl }\end{array}$} & \multicolumn{5}{|c|}{ Non treated FPV } \\
\hline $\begin{array}{c}\text { No of } \\
\text { passage }\end{array}$ & $\begin{array}{l}1^{\text {st }} \\
\text { day }\end{array}$ & $\begin{array}{l}2^{\text {nd }} \\
\text { day }\end{array}$ & $\begin{array}{c}3^{\text {rd }} \\
\text { day }\end{array}$ & $\begin{array}{l}4^{\text {th }} \\
\text { day }\end{array}$ & $\begin{array}{l}5^{\text {th }} \\
\text { day }\end{array}$ & $\begin{array}{c}1^{\text {st }} \\
\text { day }\end{array}$ & $\begin{array}{l}2^{\text {nd }} \\
\text { day }\end{array}$ & $\begin{array}{l}3^{\text {rd }} \\
\text { day }\end{array}$ & $\begin{array}{l}4^{\text {th }} \\
\text { day }\end{array}$ & $\begin{array}{c}5^{\text {th }} \\
\text { day }\end{array}$ & $\begin{array}{l}1^{\text {st }} \\
\text { day }\end{array}$ & $\begin{array}{l}2^{\text {nd }} \\
\text { day }\end{array}$ & $\begin{array}{l}3^{\text {rd }} \\
\text { day }\end{array}$ & $\begin{array}{l}4^{\text {th }} \\
\text { day }\end{array}$ & $\begin{array}{l}5^{\text {th }} \\
\text { day }\end{array}$ \\
\hline 1 & - & + & ++ & ++ & +++ & 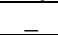 & + & ++ & ++ & +++ & & + & ++ & ++ & +++ \\
\hline 2 & - & + & ++ & ++ & +++ & - & + & ++ & ++ & +++ & - & + & ++ & ++ & +++ \\
\hline 3 & - & + & ++ & ++ & +++ & + & ++ & ++ & +++ & & $=$ & + & ++ & ++ & +++ \\
\hline 4 & - & + & ++ & ++ & +++ & + & ++ & ++ & +++ & & - & + & ++ & ++ & +++ \\
\hline 5 & - & + & ++ & ++ & +++ & + & ++ & ++ & +++ & & $=$ & + & ++ & ++ & +++ \\
\hline 6 & + & + & ++ & +++ & & + & ++ & ++ & +++ & & 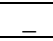 & + & ++ & ++ & +++ \\
\hline 7 & + & + & ++ & +++ & & + & ++ & ++ & +++ & & & + & ++ & ++ & +++ \\
\hline 8 & + & ++ & ++ & +++ & & + & ++ & ++ & +++ & & & + & ++ & ++ & +++ \\
\hline 9 & + & ++ & ++ & +++ & & + & ++ & ++ & +++ & & & + & ++ & ++ & +++ \\
\hline 10 & + & ++ & ++ & +++ & & + & ++ & ++ & +++ & & & + & ++ & ++ & +++ \\
\hline
\end{tabular}

$-=$ no CPE

$+=$ rounding of cells

$++=50 \%$ sheet destruction (degenerative change and necrosis)

$+++=75 \%$ sheet destruction (necrosis) 
Table (5): protection percent in vaccinated and control chicks after challenged with virulent FPV virus

\begin{tabular}{|c|c|c|c|c|}
\hline \multirow{2}{*}{$\begin{array}{c}\text { Time post } \\
\text { challenge }\end{array}$} & $\begin{array}{c}\text { Chickens } \\
\text { groups }\end{array}$ & $\begin{array}{c}\text { No. of } \\
\text { challenged } \\
\text { Chickens/group }\end{array}$ & $\begin{array}{c}\text { No. of birds } \\
\text { showing lesion } \\
\text { post challenge }\end{array}$ & $\begin{array}{c}\text { Protection } \\
\text { percent (\%) }\end{array}$ \\
\hline \multirow{3}{*}{$\begin{array}{c}3 \\
\text { w weeks } \\
\text { challenge }\end{array}$} & 1 & 25 & 1 & $96 \%$ \\
\cline { 2 - 5 } & 2 & 25 & 2 & $92 \%$ \\
\cline { 2 - 5 } & 4 & 25 & 1 & $96 \%$ \\
\cline { 2 - 5 } & 5 & 25 & 2 & $92 \%$ \\
\hline
\end{tabular}

Group (1) vaccinated SPF chickens with Treated MgCl FPV ECE.

Group (2) vaccinated SPF chickens with Treated $\mathrm{MgCl}$ FPV on CEF.

Group (3) vaccinated SPF chickens with Treated DEAE-Dextran FPV ECE.

Group (4) vaccinated SPF chickens with Treated DEAE-Dextran FPV on CEF.

Group (5) non vaccinated SPF chickens

Table (6): Results of the VNT for chickens vaccinated with treated, non treated FPV and non vaccinated chickens

\begin{tabular}{|c|c|c|c|c|c|c|c|c|c|c|c|}
\hline \multirow[b]{2}{*}{ WPV } & \multicolumn{4}{|c|}{$\begin{array}{l}\text { NI of chickens vaccinated with } \\
\text { treated FPV field dose }\left(3.7 \log _{10}\right. \\
\left.\text { TCID }_{50} / \mathrm{ml} / \text { dose }\right)\end{array}$} & \multicolumn{4}{|c|}{$\begin{array}{l}\text { NI of chickens vaccinated with } \\
\text { treated FPV field dose ( } 4.7 \log _{10} \\
\left.\text { TCID }_{50} / \text { dose }\right) \text { 10x field dose }\end{array}$} & \multicolumn{2}{|c|}{$\begin{array}{l}\text { NI of chickens } \\
\text { vaccinated } \\
\text { with non } \\
\text { treated FPV } \\
\text { field dose } \\
\left(3.7 \log _{10}\right. \\
\text { TCID50 } \\
\text { /dose) }\end{array}$} & \multirow{2}{*}{$\begin{array}{c}\begin{array}{c}\text { NI of } \\
\text { control } \\
\text { chickens }\end{array} \\
\begin{array}{c}\text { Non } \\
\text { vaccinated }\end{array}\end{array}$} \\
\hline & $\begin{array}{c}\text { FPV } \\
\text { in } \\
\text { ECE } \\
\text { with } \\
\text { MgCl }\end{array}$ & $\begin{array}{c}\text { FPV } \\
\text { on } \\
\text { CEF } \\
\text { with } \\
\text { MgCl }\end{array}$ & $\begin{array}{c}\text { FPV on } \\
\text { ECE } \\
\text { with } \\
\text { DEAE- } \\
\text { dextran }\end{array}$ & $\begin{array}{c}\text { FPV on } \\
\text { CEF } \\
\text { with } \\
\text { DEAE- } \\
\text { dextran }\end{array}$ & $\begin{array}{c}\text { FPV } \\
\text { in } \\
\text { ECE } \\
\text { with } \\
\text { MgCl }\end{array}$ & $\begin{array}{c}\text { FPV } \\
\text { in } \\
\text { CEF } \\
\text { with } \\
\text { MgCl }\end{array}$ & $\begin{array}{c}\text { FPV in } \\
\text { ECE } \\
\text { with } \\
\text { DEAE- } \\
\text { dextran }\end{array}$ & $\begin{array}{c}\text { FPV in } \\
\text { CEF } \\
\text { with } \\
\text { DEAE- } \\
\text { dextran }\end{array}$ & $\begin{array}{l}\text { FPV } \\
\text { in } \\
\text { ECE }\end{array}$ & $\begin{array}{l}\text { FPV } \\
\text { In } \\
\text { CEF }\end{array}$ & \\
\hline 0 & 0.4 & 0.3 & 0.3 & 0.4 & 0.3 & 0.2 & 0.4 & 0.3 & 0.3 & 0.3 & 0.1 \\
\hline $\begin{array}{c}1 \\
\text { week }\end{array}$ & 0.9 & 1.2 & 1.1 & 1.3 & 1.1 & 1.3 & 1.4 & 1.3 & 1.3 & 1.2 & 0.2 \\
\hline $\begin{array}{c}2 \\
\text { weeks }\end{array}$ & 1.6 & 1.4 & 1.5 & 1.3 & 1.8 & 2.0 & 2.0 & 1.7 & 1.6 & 1.7 & 0.1 \\
\hline $\begin{array}{c}3 \\
\text { weeks }\end{array}$ & 2.3 & 2.1 & 2.3 & 2.0 & 2.4 & 2.1 & 2.2 & 2.4 & 2.4 & 2.0 & 0.1 \\
\hline $\begin{array}{c}4 \\
\text { weeks }\end{array}$ & 2.1 & 1.9 & 2.0 & 1.8 & 2.3 & 2.0 & 2.0 & 2.2 & 2.1 & 1.9 & 0.2 \\
\hline $\begin{array}{c}5 \\
\text { weeks }\end{array}$ & 1.9 & 1.8 & 1.9 & 1.8 & 2.0 & 1.9 & 1.9 & 1.8 & 1.9 & 1.8 & 0.1 \\
\hline
\end{tabular}

\section{Discussion}

Usually viral vaccine producers hope to increase their production with a maximum possibility of cost reduction. One of the methods that helps in such purpose is to increasing virus infectivity titer in the vaccine product, so the main 
goal of the present study was directed to increase the infectivity titer of FPV used for vaccine production and propagated on ECE and CEF using chemical enhancers like DEAE-Dextran and $\mathrm{MgCl}$.

The cytotoxic effect of DEAE Dextran was evaluated in both CEF and ECE. The safe concentration used for DEAE-Dextran was $50 \mathrm{ug} / \mathrm{ml}$ on $\mathrm{CEF}$ and $25 \mathrm{ug} / \mathrm{ml}$ in ECE. Similar results were obtained by Kaplan et al (1967) who found that DEAE-Dextran $(50 \mathrm{ug} / \mathrm{ml})$ improved the susceptibility of cell culture to rabies virus, Zeneib Salama (2006) found that $50 \mathrm{ug} / \mathrm{ml}$ improved susceptibility of Vero cells to BEF virus, Eman et al (2011) found that 25ug of DEAEDextran is safe for ECE to increase the titer of propagated AI on ECE, Ayatollah et al (2007) mentioned that $50 \mathrm{ug} / \mathrm{ml}$ of DEAE-Dextran is the effective concentration increase CPV titer on Vero cell line and Soad et al. (1986) used the same concentration to increase FPV titer on chicken embryo rough cell (CER) and Vero cell line.

The cytotoxic concentrations of $\mathrm{MgCl}$ was determined on both $\mathrm{CEF}$ and ECE, it was found that the safe concentration is $30 \mathrm{ug} / \mathrm{ml}$ on CEF and $20 \mathrm{ug} / \mathrm{ml}$ on ECE. These result in parallel to Tsuctty and Tagaya (1970) who used $30 \mathrm{ug} / \mathrm{ml}$ of $\mathrm{MgCl}$ to increase the variola virus titer on monkey kidney cell line. Also Sahle et al (2002) used $\mathrm{MgCl}$ during propagation of $\mathrm{n}$ NDV on MDBK cell line.
By using DEAE-Dextran, the FPV titer increased gradually from 5.7 $\log _{10}$ TCID ${ }_{50} / \mathrm{ml}$ in first passage reaching to $6.7 \log _{10} \mathrm{TCID}_{50} / \mathrm{ml}$ by the 9th passage on CEF while on ECE the FPV titer increased gradually from $5.2 \log _{10}$ EID $50 / \mathrm{ml}$ in first passage reaching $6.2 \log _{10}$ $\mathrm{EID}_{50} / \mathrm{ml}$ by the $8^{\text {th }}$ passage compared to the non treated FPV which reach $6.2 \log _{10} \mathrm{TCID}_{50} / \mathrm{ml}$ and $5.7 \quad \log _{10} \quad \mathrm{EID}_{50} / \mathrm{ml}$ at $9^{\text {th }}$ passage on CEF and ECE respectively. Similar results were obtained by Lee et al (1996) they reported an increase in the Retro virus titer by 3 fold by using DEAE-Dextran, Zeneib Salama (2006), Ayatollah et al (2008) and Olfat et al (2010) recorded the increase of BEFV, CPV and SPV titer, by one log in Vero cell line by using DEAE-Dextran. Also Eman et al (2011) reported the increase haemagglutinating activity (HA) with $2 \log$ when $25 \mathrm{ug} / \mathrm{ml}$ DEAEDextran used during AI virus inoculation on ECE.

The action of DEAE-Dextran could be explained on the basses of negatively charged surfaces of both cell and viruses, so the pretreatment of CEF cell monolayer with DEAEDextran would enhance the adsorption and uptake of the virus onto such cells (Tessy et al, 2004).

The titer of FPV treated with $\mathrm{MgCl}$ was more than that treated with DEAE Dextran reaching 7.5 TCID $_{50} / \mathrm{ml}$ on CEF by the $8^{\text {th }}$ passage and $6.7 \log _{10} \mathrm{EID}_{50} / \mathrm{ml}$ on ECE in $9^{\text {th }}$ passages, similar results 
obtained by Spizizen et al (1986) who found that using of divalent cations improved DNA transfection into cell culture as much as 100 times over the DEAE-Dextran method, Hussein et al (2003) mentioned that divalent cations in the outlaying medium of PPR virus elevated its titer on Vero cells comparing with conventional method.

Sahle et al (2002) reported an increase of NDV titer on MDBK cell line using $\mathrm{MgCl}$. Also Tsuctty and Tagayab (1970) who mentioned that vaccinia virus titer increased one and half $\log$ using $\mathrm{MgCl}$ in Vero cell line. Graham and Van der Eb (1973) explained the mode of action of $\mathrm{MgCl}$ on the basis of divalent cations such as calcium and magnesium promote the uptake of DNA into cells (Transformation). Also Milan and George (1986) mentioned that the action of $\mathrm{MgCl}$ could be explained on the basis of enhancing adsorption and increasing virus release, both contribute to enhancement of virus titer and accelerate the onset of CPE in CEF. Similar explanation obtained by Abeer et al (2010) who reported that electrolytes potentially facilitate the adsorption and penetration of FMD to BHK cells by increasing virus attachment to the cell receptors.

The onset of CPE of FPV treated with DEAE- Dextran and $\mathrm{MgCl}$ appeared earlier than that of the non treated FPV on CEF by one day.
Similar results were obtained by Zeneib Salama (2006) by using DEAE-Dextran with BEF on Vero cell line.

Protection percent of vaccinated chickens with enhanced FPV vaccines with DEAE-dextran and $\mathrm{MgCl}$ in both ECE and CEF were $96 \%, 92 \%, \quad 96 \%$ and $92 \%$ respectively in these results are the same as obtained by Namaa (1998) who examined the protection rate for FPV vaccine propagated on both CEF and ECE.

The neutrization index of vaccinated chickens with field dose (3.7 $\left.\log _{10} \mathrm{TCID}_{50} / \mathrm{ml}\right)$ of non treated propagated FPV on ECE and CEF were the same as treated FPV with DEAE-dextran and $\mathrm{MgCl}$ propagated on ECE and CEF cells. Moreover the NI of the vaccinated chickens with treated FPV vaccines (10x field dose $4.7 \quad \log _{10}$ TCID $_{50} /$ dose) giving slightly higher NI. The same results obtained by Aytollah et al (2007) who discrimated between the field dose and 10x field dose of treated CPV vaccine with DEAE-Dextran.

\section{Recommendations}

This study recommended the use of $\mathrm{MgCl}$ and DEAE-Dextran during production of FPV vaccine in order to obtain high virus titer leading to increase vaccine production and reduction of vaccine costs.

\section{Reference}

Abeer.M.M; Khodeir.M.H and Hussein A. M. H.(2010): The 
effect of some electrolytes on the susceptibility of BHK to FMD virus. $3^{\text {rd }}$ inter. Conf. Virol., SP. Issue, 229-236, 2010.

Anderson, E.C.; Masrer, R.C. and Mowat, $G$ N (1971): Immune response of pigs of inactivated foot and mouth disease vaccines. Response to DEAE-Dextran and saponin adjuvant vaccines. Vaccines. Res. Vet. Sci., v.(12) 351-357.

Ayatollah.I.B; Aboul Soud E.A. Hussein; H. A.; Soad M. S. And El-Sanousi A.A (2007): Preparation of an enhanced live attenuated camel pox virus vaccine. Egyptian J. Virol. 4 (2007) 31-39.

Carl D. M, Ran W A, Ahmed E A, Nancy A B and Michael S. M. (1997): A novel method for DEAEdextran mediated transfection of adherent primary cultured human macrophages. Journal of Immunological Methods (211), 7986.

Charles H. Cunningham (1973): A Laboratory Guide in Virology by . 7th. ed. Burgess Publishing Co., Minneapolis, Minnesota. Pages (320 -325).

Eman A. Hassan,. Abdel Wwanis. N. A AND Susan K. Tolba (2011): study of incorruption DEAEDeaxtran during production of local Avian influenza (AI) inactivated vaccine Egypt. J. Agric. Res., 89 (3).

Fiala, I.M. and Kenny, G. E. (1966): Enhancement of rhinovirus plaque formation in human heteroploid cell cultures by magnesium and calcium. Journal of Bacteriology 92, I7IO.

FialaI, M. \& Kenny, G. E. (I967): Effect of Magnesium on replication of rhinovirus HGP. Journal of Virology i, 489.

Graham, F.L.and Van der Eb. (1973): A new technique for the assay of infectivity of human adenovirus 5 DNA. Virology, 52:456-467.

Hussein, A.H.M.;Hanan, S.' Abdel Raouf; Hanan, M.S.ElZawahery and Daoud, A.M.(2003): Attempts for improving the keeping quality of PPR tissue culture attenuated vaccine J. Egypt. Vet. Med. Ass., 63 (4) 195-200.

Kaplan, M.M., Wiktor, T.j.;Maes, R.F., Campbell, J.B.and Koprowski, H.(1967): Rabies virus replicationin presence of DEAE-Dextran. J.Virol.,140-145. Lee A S. Kim A P. Robbins A B. Kim D (1996): Optimization of environmental factors for the production and handling of recombinant retrovirus. Appl Microbiol Biotechnol (1996) 45:477Đ 483.

Margot H, Sigrun H, Y. S, Malik, S M. and Goyal.(2005): Improved In Vitro Cultivation of Swine Influenza Virus Intern J Appl Res Vet Med • Vol. 3, No. 2, 123-128.

Milan. F and George. E. K (1986): Effect of Magnesium on Replication of Rhinovirus HGP' JOURNAL OF VIROLOGY, June , p. 489-493. 
Namaa Abd El-Aziz (1998): Study on trail for preparation of fowl pox vaccine locally on embryonated specific pathogen eggs. MD thesis, poultry Dep., Fac. Vet. Med., Cairo Univ.

Graham, F.L.and Van der Eb. (1973): A new technique for the assay of infectivity of human adenovirus 5 DNA. Virology, 52:456-467.

Office International Des Epizootic (OIE) (2012): Recommended Diagnostic Technique and Requirements for biological products, Volume 1 (chapter 2.3.9. pp 507-514).

Olfat. E. N, Namaa. A.M, Manal .A. and Mervat. M. A (2010): Effect of DEAE-Dexran on the infectivity titer of sheep pox virus in- vitro and in vivo Beni-Suef Veterinary Medical Journal $6^{\text {th }}$ Scientific Coference PP.122-172

Pango, J. S and Mccutchan j. H. (1969): Enhancement of viral infectivity with DEAE-Dextran: Application to development of vaccines prog, Immunobiol. Standard 3, 152-158.

Reed , L.J. and Munech, $\mathrm{H}$ (1938): A simple method of estimating fifty percent end points. Am. J. Hyg,., 27:493-497.

Russell, W. Russell, W. C., Tiayashl, K., Sanderson, P. J. and Perera, H. G. (1970): Enhancement of Adenovirus Plaque Formation on HeLa Cells by Magnesium Chloride J. gen. Virol. (I970), 9, 251-255.

Sahle M, Burgess W.G. and Kidanemariam A. (2002):
Multiplication of the V4 strain of Newcastle disease virus in Madin Derby bovine kidney cells. Onderstepoort Journal of Veterinary Research, 69:201-206.

Sasaki, K.;Furukawa, T. and Potkin, S. A. (1981): Enhancement of infectivity of cell free varicilla zoster virus with diethylaminoethyyl 1- dextran. Pro, soc. Exp Biol. Med. (USA), v. 166, 281-286.

Stott, E.J. and Tyrrell, D. A. J.(I968): Some improved techniques for the study of rhino viruses using HeLa cells. Archiv fur die gesamte Virus for schung 230, 236.

Soad. M. A and Reda . M. I and Monera. N. (1986): Immunological and virological studies on fowl pox vaccine. $\mathrm{Ph}$. D theses. Poultry. Cairo Universty.

Spizizen, J.;Reilly, B.E. and Evan, A.H.(1986): Microbial transformation and transfection. Annu. Rev. Microbil. 20; 371-400.

Tessy, Y.:Tasutomu, Y.:miyuki, I. and Motohiko, O.(2004): Factors improving the propagation of simkania negevensis strain $\mathrm{Z}$ in cell culture. Jpn. J. Infect., 57:103-106.

Tripathy, D.N. and Reed W.M (2008): Pox, In A laboratory manual for the Isolation, Identification and characterization of avian pathogens. 5th Edn. American Association of Avian pathologists Ch.5 : 116-119

Tsuctty. Y and Tagaya .I (1970): Plaque Assay of Variola Virus in a Cynomolgus Monkey Kidney Cell 
Line. Archiv fiir die gesamte Virusforschung 32, 73--81 .

Yuki E, Junko H.I , Masayasu O. Masaaki M. Jun Y. Tomohiko T. Naoji $K$ and Yasuhiko $O$ (2009): Mechanism of introduction of exogenous genes into cultured cells using DEAE-Dextran-MMA graft copolymer as non-viral gene carrier. Molecules , 14 (7), 2669-2683

Zeneib, T. S. Salama (2006): Effect of Dextran on the infectivity titer of Bovine Ephemeral Fever Virus produced on different cell cultures. Minufuya Vet.J.Vol.4 No.1 . 189-194

\section{محاولات لزياده القوه العياريه للقاحات جدرى الطيور المنتجه على البيض المخصب الخالى من المسبيات المرضيه وخلايا الزرع النسيجى المئه البفئ}

عبد الرازق بدوى عبدالرازق ـاميره عبد النبى السعيد ـ امل احمد فتوح ـ ايه الله ابراهيم بسيوني -

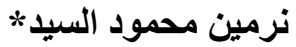

$$
\text { معهل بحوث الامصال واللقاحات البيطريه ـ *الدعرل المركزى للرقابه على المستحضرات الحبويه }
$$

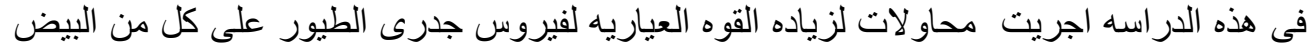

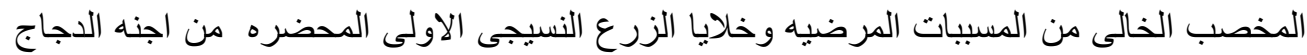

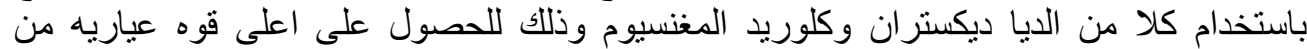

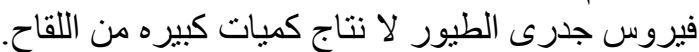

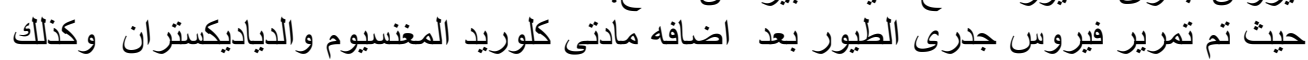

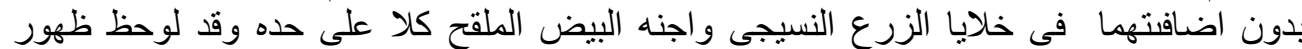
اسر ع على الخلايا الاوليه مع زياده القوى العياريه للفيروس على كلى كل من البيض و والخلايا

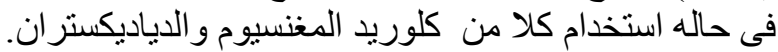

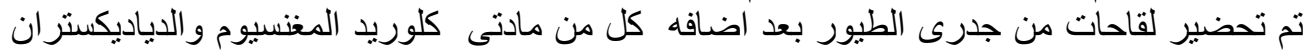

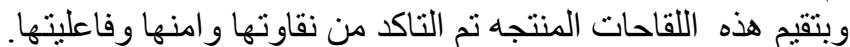

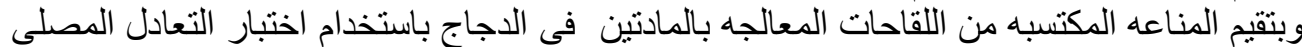

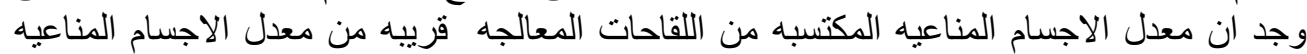

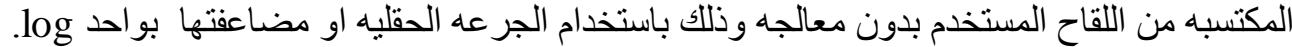

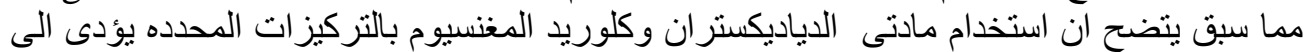
زياده القوه العياريه لفيروس جدرى الطيور مما يزيد انتاج اللقاح و تقليل تكاليف انتاجها. 